\title{
Fibulae with Canid Protome (Tierkopffibeln) in Romania
}

\section{Daniel Spânu}

\begin{abstract}
At the present stage of the research, 12 fibulae with canid protome (germ. Tierkopffibeln) were discovered on the territory of Romania. With the exception of one item from Ocnița (Wallachia), all the other fibulae come from the Eastern Carpathians area (Eastern Romania). These fibulae provide some valuable clues to the local chronology and allow some insight into the phenomena of imports circulation and acculturation in pre-Roman Dacia.
\end{abstract}

Keywords: Fibulae with canid protome (Tierkopffibeln), early imperial period, pre-Roman Dacia, imports, acculturation

\section{Preamble}

The fibulae with canid protome on the bow (germ.: Fibeln mit beißendem Tierkopf / Tierkopffibeln, acronym: TKF) form a particular group of strongly profiled fibulae of the early Roman imperial period and were perceived as Noric derivates of Almgren 67 type (Werner 1954, 151-152; Demetz 1999, 137, 195). The shape of the protome with an elongated muzzle biting the foot of the fibula may recall the head of a carnivore of the species canidae. The morphological classification of these fibulae has been elaborated gradually, especially based on the researches of Joachim Werner, Manfred Menke and Stefan Demetz (Werner 1954; Menke 1974; Menke 1977; Demetz 2000, 15-18). The latter has the largest and most up-to-date collection of data. Based on nuanced morphological and stylistic distinctions, Stefan Demetz proposed the most refined classification of the variants of this type (Fig. 1). The fibulae with canid protome have not yet been signaled in the North-Pontic space (see Kropotov 2010; Hellström 2018). This aspect puts in a particular light the Romanian discoveries: these form the eastern extremity of the spreading area of the provincial fibulae with canid protome. In general, the western and central European debates have been focused preferentially on the spread of these fibulae between the circum-alpine provinces and Scandinavia (Böhme-Schönberger 1994, 514515, fig. 111; cf. Jahn 1952, 95, fig. 1; Werner 1954, 156, fig. 3; Müller 1985, 83; Bemmann 1999, 151-154, fig. 2; Demetz 2000, 19-20 with older literature). The fascination exercised by the Ambre Road has been irresistible and the eastern discoveries were overlooked. Meanwhile, the specimens found in Romania were previously documented and illustrated, and their reference to the central 


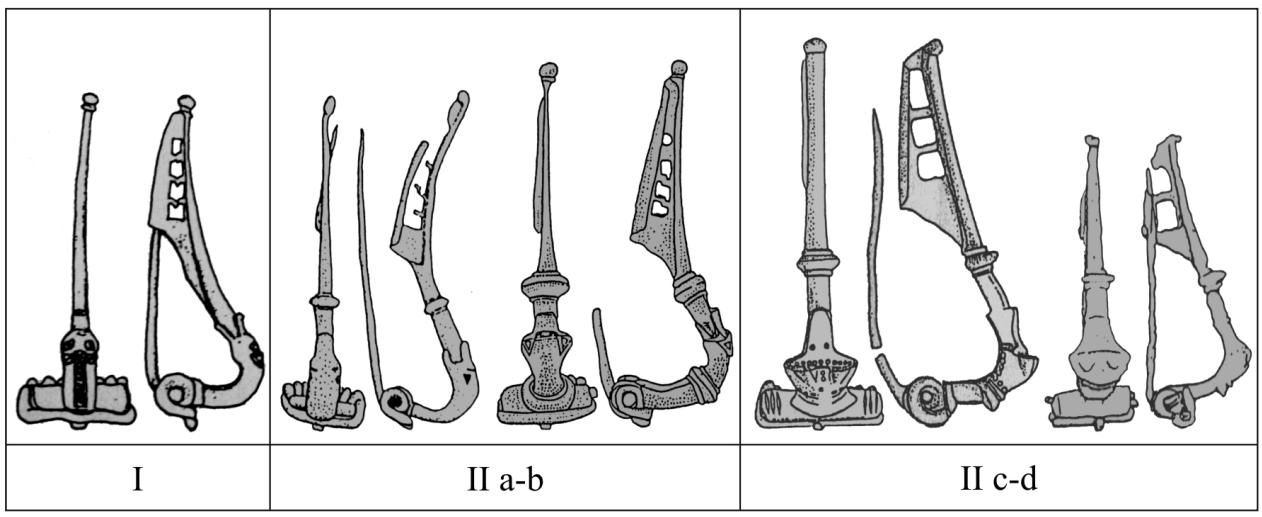

Fig. 1. Systematizing Demetz's classification (drawings after Demetz 2000).

European classifications has never been satisfactorily undertaken. This paper is intended to compensate for these shortcomings.

\section{Current Stage of Data in Romania}

In the current stage of the research, from Romania can be listed 12 certain fibulae with canid protom (Fig. 2). These come exclusively from extra-Carpathian finds: Ocnița in Vallachia and Brad, Cândeşti, Poiana and Răcătău de Jos in Moldavia. So far, this kind of fibula has never been identified in Transylvania (Fig. 5). Except the only silver fibula from Cândeşti, all other items found in Romania were made of bronze. A fibula with hinge system (?) from Poiana appears to have been decorated with an extremely simplified canid protome (cat. no. 10). If the published drawing is accurate (Vulpe, Teodor 2003, 589, fig. 110/1; this image is reproduced here in Fig. 2/10), this item would represent the only case of fibula with canid protome with hinge (and not with spring) known so far. In any case, the archaeological vestiges from Poiana reunite more fibulae with canid protome than in all other discoveries of the rest of Romania. In other localities only one item was discovered. Most likely, a regional center of distribution of this type of fibulae has been operating in Poiana.

The majority of fibulae come from different unsatisfactory documented contexts (see Appendix) within small oppida or "dava"-type settlements of regional importance. (On the compatibility vs. incompatibility between "oppidum" and "dava" see Florea 2011, 173). Two fibulae from Poiana were discovered in funeral contexts: one of them was found in the wall of the burial chamber in "Movila cu pietre" tumulus (Fig. 2/11; cat. no. 11); the other comes from the inventory of an ustrinum in the "Movila Hârtop" tumulus (Fig. 2/12; cat. no. 12). 

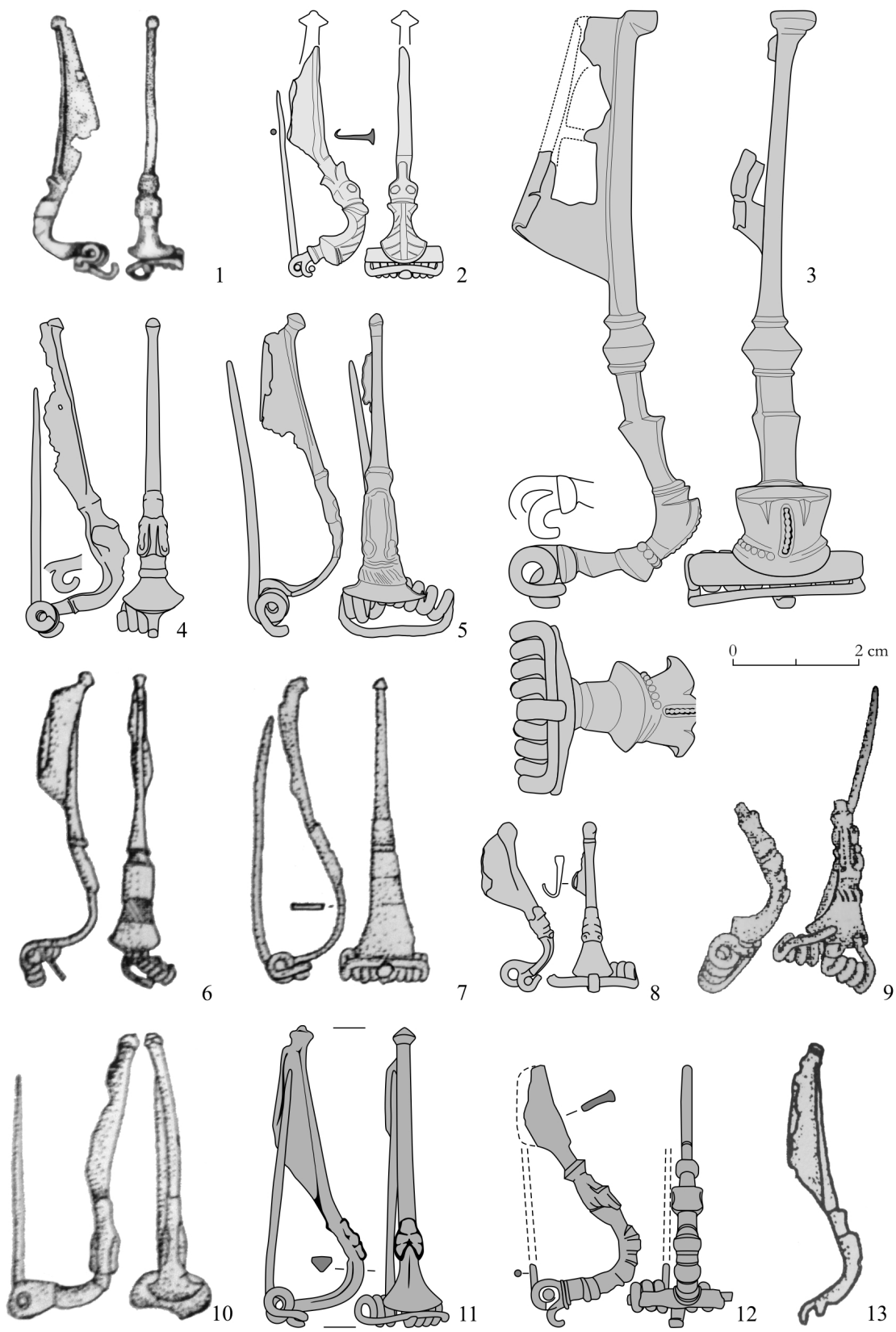

$\mathrm{cm}$

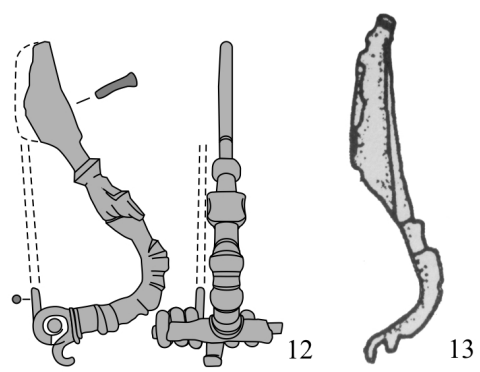

Fig. 2. Fibulae with canid protome in Romania. 1: Brad; 2: Cândeşti; 3: Ocnița; 4-10: Poiana "Cetățuie"; 11: Poiana "Movila cu pietre"; 12: Poiana "Movila Hartop"; 13: Răcătău de Jos. 1: after Ursachi 1995, 499, pl. 204/2. 2, 4-5, 8 şi 11-12: after the original. 3: graphic processing of a draw after original by Cristina Georgescu. 6-7 and 9-10: after Vulpe, Teodor 2003, 573, fig. 94/1-2, 5-6 şi 589, fig. 110/1. 13: after Căpitanu 1989, 120, fig. 104; 1 and 13: uncertain scale. 1, 3-13: bronze; 2: silver. 


\section{Short History of the Research in Romania}

Ecaterina Dunăreanu-Vulpe has the merit of recognizing for the first time in the Romanian literature the presence of a canid protome on the bow of a fibula from Poiana (Fig. 2/11), as well as its provincial origin (Dunăreanu-Vulpe 1938, 164, fig. 15/3). However, the fibula was not included in subsequent repertoires of Roman imports (Glodariu 1974; Glodariu 1976). During the national-communist era (1964-1989), the Roman origin of other later discovered fibulae, such as those from Ocnița and Cândeşti was not recognized (Berciu 1981, 30; Bobi 1987, 507), and the protomes on the items from Brad and Răcătău de Jos were not even noticed (Ursachi 1987, 119, fig. 12/9; Căpitanu 1989, 120, fig. 10/4; Ursachi 1995, 228). Instead, some scholars were seduced by the problematic analogy between the canid ornaments of some fibulae and the wolf's head on the "Dacian" standards called dracones (Bobi 1987, 507; Rustoiu 1989, 143; the alleged relationship between Dacians and wolves was critically examined by Dana 2000, 167-173).

The distinct typology and the provincial origin of the fibulae with canid protome found in Romania were coherently outlined by Aurel Rustoiu. Under the influence of the anthropomorphic interpretation of its decoration, previously proposed with naivety by Berciu, the fibula from Ocnița was classified separately (type 25: Rustoiu 1997, 58) from the other items gathered in type 21 (Rustoiu 1997, 55-56, 113, list 18, 220, fig. 64/1 and 222, fig. 66/1-3.). No fibula from Poiana was illustrated. For chronology, Aurel Rustoiu retained the unduly delayed dating (Tiberius - Domitianus) proposed by Vinko Šribar (Šribar 1968), but omitted the earlier dates (Augustus - Claudius), as well as the more consistent arguments of some scholars as Joachim Werner, Günter Ulbert, Emilie Riha, Manfred Menke, Rosemarie Müller, Stefan Demetz a.o. (Werner 1954, 152; Ulbert 1960, 52; Riha 1973, 77; Menke 1977; Hedeager, Kristiansen 1981, 103; Müller 1985, 83; Demetz 1993). The conclusions of more recent syntheses and interdisciplinary studies (Demetz 1999, 137-147 and Demetz 2000, 21 accepted by: Gugl 2001, 315, Sedlmayer 2009, 25-26, Quast 2009, 110; Blakenfeldt 2015, 31; Grabherr 2015, 154-155 a.o.) require the abandonment of the Vinko Šribar's long chronology. For exemple, the results of the ${ }^{14} \mathrm{C}$ analyses performed on the grave 872 from Czarnówko (Michalska et al. 2015, 254, fig. 1/1) do not contradict the dating of the fibulae with canid protome in the first half of the $1^{\text {st }}$ centuty AD.

\section{Fibulae with Canid Protome in Romania and Demetz's Classification}

The fibulae from Brad, Cândeşti and Răcătău de Jos (cat. no. 1-2, 13, Fig. $2 / 1-2,13$ ) as well as most of the fibulae from Poiana (cat. no. 4-11, Fig. 2/4- 
11) are decorated only with a protome; additional biconical knots are missing. These ornamental features correspond to the Demetz TKF I type (Demetz 2000, 15-16). According to Stefan Demetz, such items were produced in the East-Alpine region (Noricum and Pannonia) and can be dated in the Augustus-Claudius period, in the first half of the $1^{\text {st }}$ century AD (Demetz 2000, 21). Only the fibula from Cândeşti has a plate protecting the spring. In the case of some fibulae from Poiana (cat. no. 5, 6, 9, Fig. 2/5, 6, 9), the bow was engraved with a group of oblique incisions placed behind the zoomorphic head - probably a suggestion of a ridge. Such details have no analogies in central Europe. Moreover, the protomes of some East-Carpathian fibulae (Fig. 2/1, 6-8, 10, 13) were extremely simplified and schematized and reflect a pronounced stylistic degeneration compared to the East-Alpine models. These particularities may reflect the brand of a peripheral and coarsening workshop. In favor of this interpretation, the absence of any à jour decoration of the catch-plates (Fig. 2/1-2, 4-11, 13) can be also invoked.

The fibula from "Movila Hârtop" tumulus in Poiana (cat. no. 12, Fig. 2/12) illustrates a more complex ornamentation: the protome is preceded by several knots, and the spring is protected by a small plate. These details are specific to the Demetz TKF IIbl variant, dated also in the first half of the $1^{\text {st }}$ century AD (Demetz 2000, 21).

The biggest fibula with canid protome from Romania is the one discovered in Ocnița $(9,5 \mathrm{~cm}$ in length - almost twice the length of most other fibulae: see Fig. 2). The complex ornamentation of the bow and the a jour openings in the catch-plate are specific to the Demetz TKF IId type (cf. Demetz 2000, 28 and 31, fig. 2/5, 32, fig. 3/5; Riha 1973, 77, tip 2.12, pl. 10/no. 270). The origin of the Ocnița fibula is most likely West Alpine (raetian) and its import in Dacia could be dated at the latest (!) in the Neronian period, at the end of the second third of the $1^{\text {st }}$ century AD.

\section{The Chronological Importance of "Movila Hâtop” Inventory}

The "Movila Hârtop" tumulus from Poiana contains the only inventory in Romania in which e fibula with canid protome is associated with expressive chronological markers as well as with jewels of local tradition as the spoon fibulae and the spiral rings with ending plates on silver (Fig. 3). The tumulus was partially investigated by Radu Vulpe in the pre-War time (1931 and 1936). Its inventory was introduced slowly and with great difficulty in the scientific knowledge (Vulpe et al. 1952, 210: first short mention; Vulpe 1976, 208-209: 


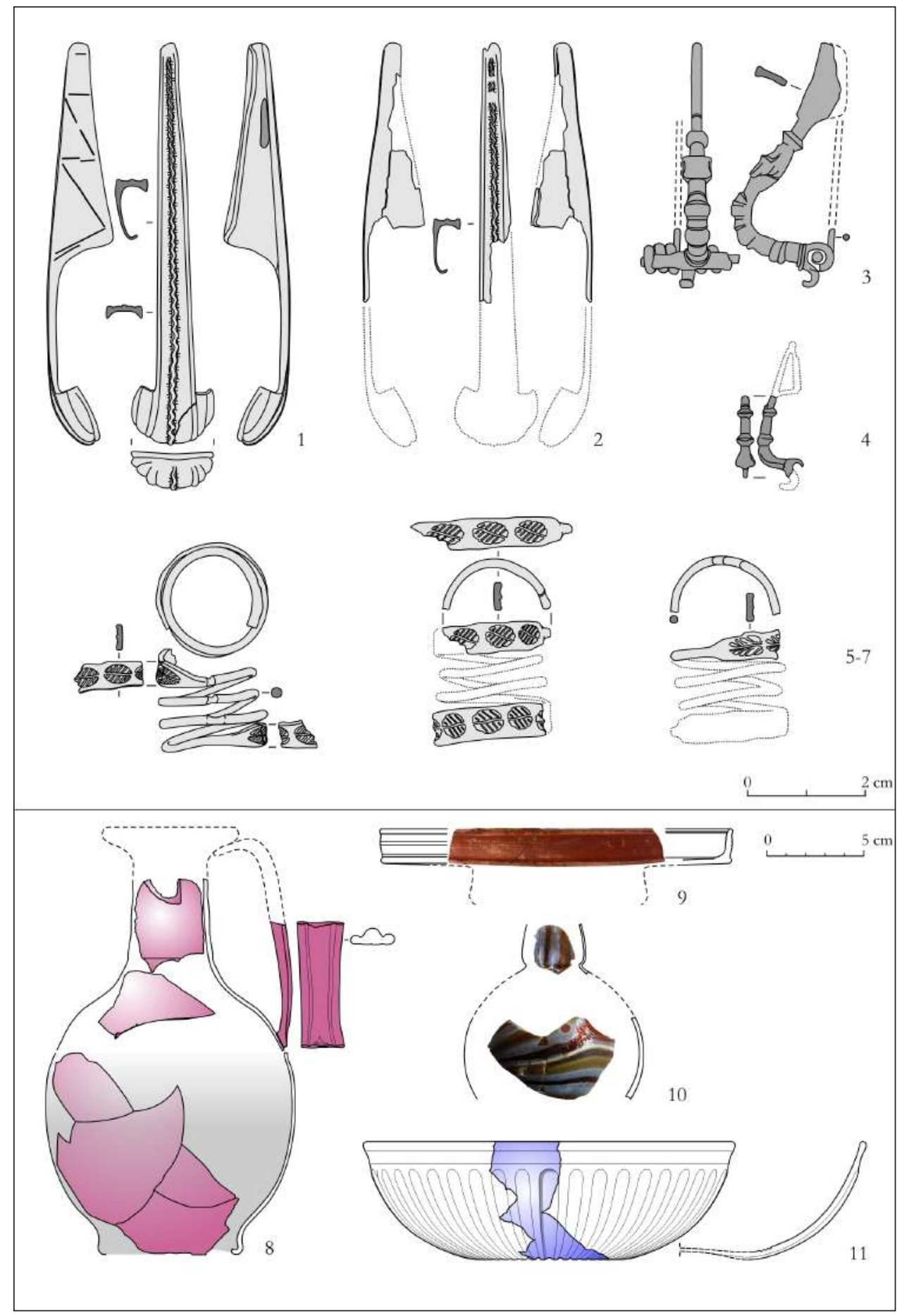

Fig. 3. Fibulae, spiral rings and imported vesseks from the "Movila Hârtop" inventory. 1-2 and 5-7: silver; 3-4: bronze; 8, 10-11: glass; 9: ceramics (terra sigillata); after the original. 
brief presentation without illustration; Spânu 2009, 88-90, fig. 3, Spânu 2012a, 235, pl. 97/3, Spânu 2012b, 169-171, fig. 6/3: partial illustration of the inventory). A systematic debate of the tumulus "Movila Hârtop" is now underway. Recently (2016), in the warehouses of the Archaeological Institute in Bucharest were found some lost and hitherto unpublished imports from "Movila Hârtop" tumulus: the fragment of a terra sigillata plate (Fig. 3/9; for analogies and their dating in the first half of the $1^{\text {st }}$ century AD see Hayes 1973, 427-428, form 8 , no. 24, 444, pl. 82/24; Hayes 2008, 41-44, 165, no. 466-467, fig. 16/466-467; Bossman, de Weerd 2004, 44; Eschbaumer 2011, 29-30; cf. Mocanu 2016, 125), the fragments of a glass jug - probably a specimen of Isings 52 type (Fig. 3/8) and the fragment of a blue-cobalt glass bowl of Isings 3a type (Fig. 4/11; for bot glass vessels see Isings 1957, 17-19 and 69-71; Biaggio Sinona 1991, 192 195; Isings, van Lith 1992, 10-11). According to the diaries of the old field excavations (accesible only after 2016), the inventory from "Movila Hârtop" also included a norico-pannonian fibula of Almgren 236 type (Fig. 3/4). Its poor preservation shape prevents an accurate reporting to the Jochen Garbsch's classification (Garbsch 1965, 26-49). However, the small dimensions of the item correspond to some specimens included in the Almgren $236 \mathrm{~b}$ and c variants (Garbsch 1965, 28-32). The imports from this spectacular inventory allow a chronological framing of the "Movila Hârtop" tumulus in Claudian - Neronian period, respectively during the second third of the $1^{\text {st }}$ century AD (beginning of the B2a phase of the Roman period).

Due to its extravagant goods, the "Movila Hârtop" burial could be compared to the 'princely' graves of Lübsow type from North-Central Europe and South-Scandinavia (Eggers 1953; Gebühr 1974; cf. Völling 2005, 203). The synchronism between the "Movila Hârtop" burial and the Lübsow-type graves is provided precisely by the fibulae with canid protome (cf. Tejral 1998, 388; Quast 2009, 110; Schuster 2010; Blakenfeldt 2015, 31). An example is granted by the fibulae found in the Bendstrup burial, dated in the Bla phase of the Roman period (Hedeager, Kristiansen 1981, 94-103).

For the local chronology of early Roman period, the "Movila Hârtop" inventory holds a particular relevance: its chronological markers allow the latest dating of the spoon fibulae which illustrate a late La Tène tradition. However, this circumstance must be carefully discerned. The spoon fibulae type is one of the guiding 'fossils' of the latest phase of the 'Dacian' hoards (Horedt 1973, 151; Rustoiu 1997, 49-50; Spânu 2012a, 145), together with denarii issued exclusively in the first decades of Augustus's reign (all termini post quem are BC!). In this way the latest 'Dacian' hoards could be well framed in the Augustan period, respectively in the B1 phase of the Roman period (Spânu 2012a, 
142-145; Spânu 2012b, 171). These later hoards do not contain post-Augustan prestigious goods similar to those from the "Movila Hârtop" burial. Thus, the burial from Poiana becomes iconic for a chronological sequence subsequent to the hoards. At the same time, the differences between the spoon fibulae from "Movila Hârtop" and those from the hoards should be noted: the first ones have a pseudo-filigree and punched ornamentation on the bow-plate (Fig. 3/12 ), absent in the case of the latter. Together with other similar items from the Cârlomăneşti and Răcătău de Jos settlements (Babeş 2010, 143, fig. 6 right/up; Căpitanu 1976, fig. 41/1), the "Movila Hârtop" spoon fibulae make up a particular and probably later variant of this type. In other words, the tradition of the spoon fibulae survived the 'Dacian' hoards (cf. Rustoiu 1997, 48-49). As I will show below, several ornamental motifs on some spoon fibulae from Poiana or Ocnița can be considered as aesthetic takeovers inspired by certain Roman fibulae types. Among these types we can also include the provincial fibulae with canid protome.

\section{Imitation and Acculturation}

The extreme simplification of the protome and the threadlike aspect of some of the fibulae from Poiana reflects an advanced stylistic and technological depreciation, specific to a peripheral workshop. The question may be asked whether these fibulae with very simplified morphology were produced on the spot. In the absence of half products and of satisfactory archaeological evidence, this hypothesis is fragile, but can be corroborated with the presumption of the activity of itinerant (provincial?) craftsmen in Poiana (Rustoiu 2000, 339; Rustoiu 2002, 200). Unfinished strong-profiled fibulae of Almgren 67 and 82 types were documented here (cf. Vulpe, Teodor 2003, 61; Spânu 2019, 432433). From the perspective of this hypothesis, the fibulae with canid protome from Poiana do not represent 'barbarian' imitations but are the result of an import of technology and Roman aesthetic models in Barbaricum.

The impact of import of fibulae with canid protome in the east of Romania and in particular in Poiana is different from the effects of the import of similar items in South Scandinavia. The fibulae with canid protome enjoyed a particular appreciation on the shores of the Baltic Sea where they were imported since the beginning of the $1^{\text {st }}$ century $\mathrm{AD}$ and where they were imitated until the beginning of the $2^{\text {nd }}$ century AD (Jahn 1952, 97; Hedeager, Kristiansen 1981, 94103, fig. 9-19). Scandinavian or local 'barbarian' imitations of the circum-alpin type were not evidenced in pre-Roman Dacia. However, the import of fibulae with canid protome and/or the import of their technology area did not remain 

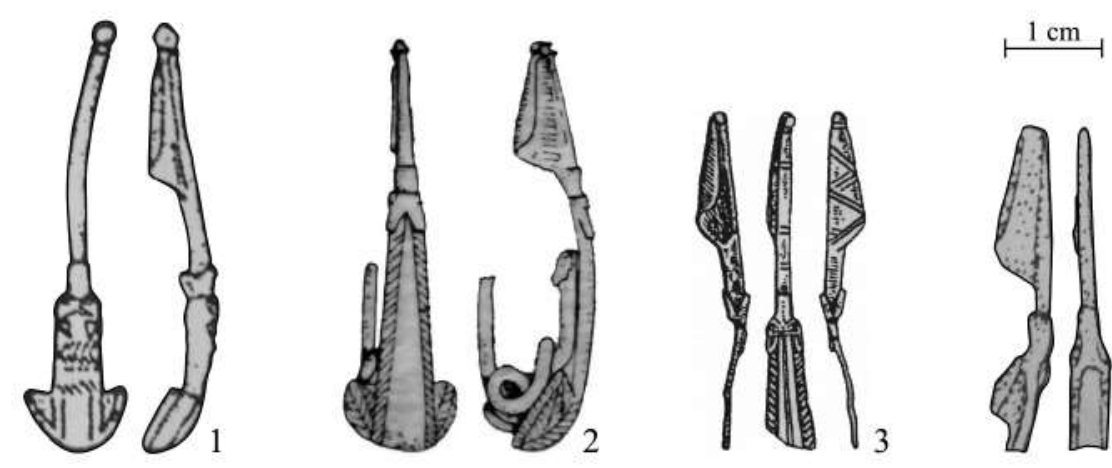

$\mathrm{cm}$

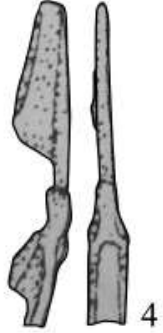

Fig. 4. Spoon fibulae with canid protome. 1: Craiva, after Rustoiu 1989, 139, fig. 2/5. 2-3: Ocnița, after Berciu 1981, 88, fig. 20/1, 211, pl. 36/5 (2: uncertain scale). 4: Poiana, after Vulpe, Teodor 2003, 581, fig. 102/8. 1-4: bronze.

without local echoes. From Craiva (a complete item), Ocnița (a complete and a fragmentary item) and from Poiana (a fragmentary item) come a few spoon (!) fibulae with canid protome on the bow-plate (Fig. 4; Berciu 1981, 87-88, fig. 20/1, 211, pl. 36/5; Rustoiu 1989, 137, no. 5, fig. 2/5; Vulpe, Teodor 2003, 215, no. 138, 581, fig. 102/8). In the case of fragmentary items, the trapezoidal shape of the catch-plate (specific to the spoon-fibulae) and not triangular (as the catch-plates of the strongly profiled fibulae) makes the typological framing proposed in the literature plausible. The well-preserved fibulae from Craiva and Ocnița (Fig. 4/1-2) convincingly attest the integration of the canid protome inspired by circum-Alpine types in the decoration of a local traditional fibula-shape. Thus, it can be considered that the local tradition and the provincial tradition could be intertwined. However, at the scale of entire pre-Roman Dacia, such 'interbreedings' are isolated and have not enjoyed a general appreciation (Fig. 5). The spoon fibulae from "Movila Hârtop" were not decorated with canid protome, but their pseudo-filigree/punched decoration could be inspired by that of other Roman fibulae, such as Aucissa or Langton-Down types, especially attested in the settlement of Poiana (e. g. Vulpe 1957, 150, fig. 5/3; Vulpe, Teodor 2003, 583, fig. 104/4-6).

Most likely, the oppida from Poiana and Ocnița did not host only outlets for early imperial imports but represented effervescent craft centers, where Roman technological and aesthetic models were adopted and filtered according to the local needs and tastes. During the $1^{\text {st }}$ century AD, Poiana and Ocnița can be considered as main focal points of acculturation to Roman cultural values in the South- and East-Carpathian space. 


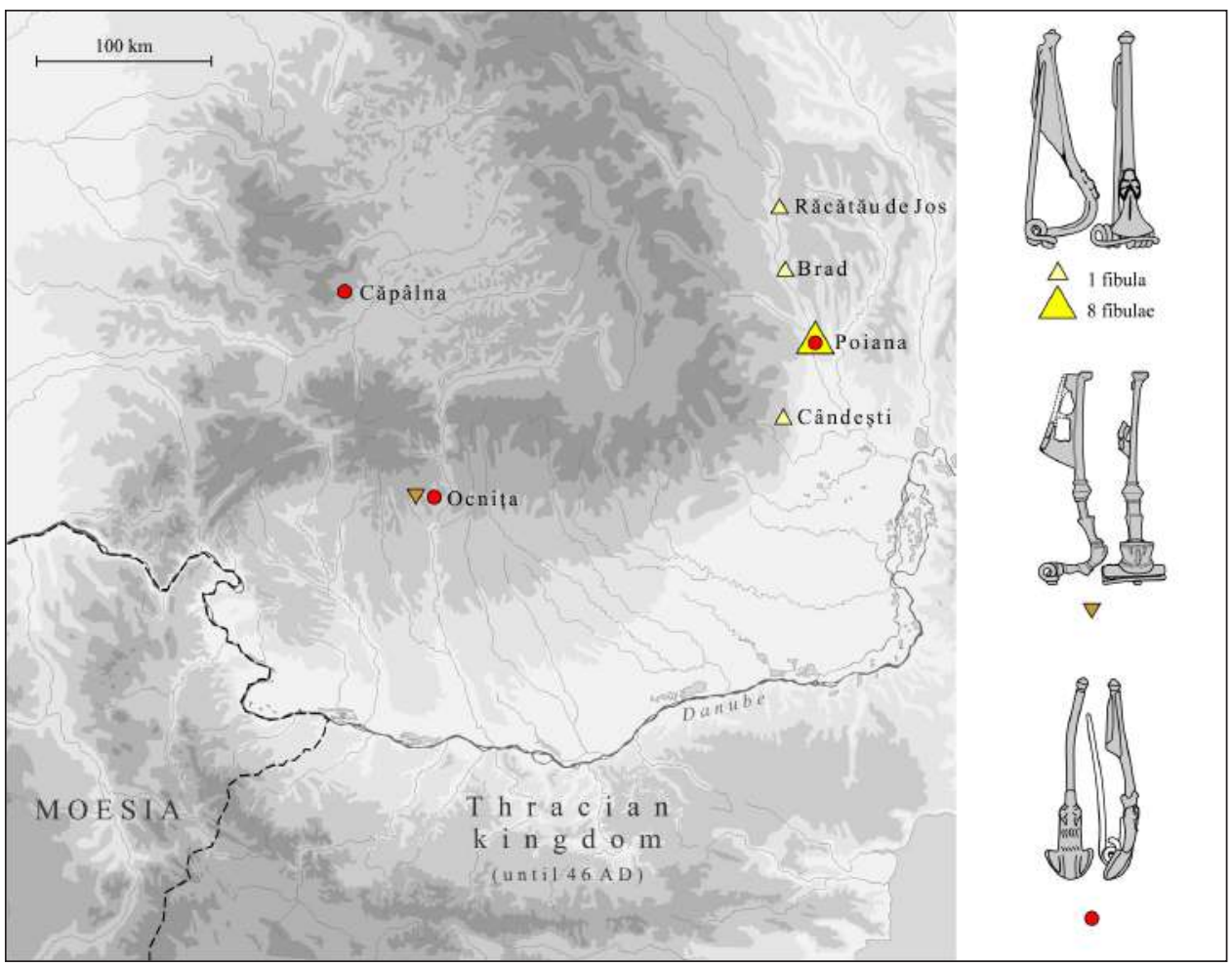

Fig. 5. Spatial distribution of the provincial fibulae with canid protome and the spoon fibulae with protome in pre-Roman Dacia.

\section{Conclusion}

Except for the item from Ocnița (probably a later one), the fibulae with canid protome were imported in the east-Carpathian area during a period (the first half of the $1^{\text {st }}$ century AD) when the southern bank of the Lower Danube (Ripa Thraicae) had not yet been integrated into the province of Moesia but was controlled by the client kingdom of Thrace (Fig. 5; cf. Matei-Popescu 2018). Therefore, the import of fibulae with canid protome into the east of Romania could not be explained as the result of a border trade, but as a display of particular long-distance relations maintained between Barbaricum and Rome since the Augustan era. The inventory of the "Movila Hârtop" tumulus convincingly mirrors this circumstance.

Hunt's Pridianum (British Museum, papyrus 2851) mentions the detachment of Roman military units from Moesia to Buridava and Piroboridava, sometime during the reign of Emperor Traianus (Fink 1958; Syme 1959; Vulpe 1960; Gillam 1962). The two toponyms were tracked down in Ocniţa and Poiana (Vulpe 1960; Vulpe 1964, 233; Berciu 1981, 8 a.o.): that is precisely 
in the centers where we find most of the specimens (Poiana) and the largest specimen (Ocnița) of fibulae with canid protomelisted in Romania. These fibulae and other provincial forms (as Aucissa type, Almgren 236 type, Langton Down type etc.) were imported long before the advance of the Roman troops mentioned in Hunt's Pridianum. Thus, in the century preceding the military conquest of Dacia, markers of a previous but genuine cultural 'conquest' can be noticed. Roman fibulae and, perhaps even their producers, arrived North of the Lower Danube well before the legions and cohorts.

\section{Appendix}

\section{Catalog of the Fibulae with Canid Protome in Romania}

1. Brad (Negri commune, Neamț county). Site: "Cetatea dacică”. Circumstances of the discovery: research excavation made by V. Ursachi (1963-1984). Context: settlement, filling of the defensive ditch (according to Ursachi 1995, 228) or level IV (according to Ursachi 1995, 499). Type: Demetz TKF I (?). Technical data: bronze; unknown lenth. Fig. 2/1. Storage institution: Muzeul de Istorie şi Arheologie, Piatra Neamț, inv. 5899 (?). Lit.: Ursachi 1995, 228 (c1), 499, pl. 204/2, 561, pl. 328/23.

2. Cândeşti (Dumbrăveni commune, Vrancea county). Site: "Coasta Banului". Circumstances of the discovery: research excavation made by M. Florescu and V. Bobi in 1972. Context: pre-Roman settlement level. Technical data: silver; lenght: $3,8 \mathrm{~cm}$; wight: 5,3 g. Fig. 2/2. Storage institution: Muzeul de Istorie, Focşani, inv. 17159. Lit.: Bobi 1987, 507-509, fig. 2.

3. Ocnița (Vâlcea county). Sit: right bank of "Pârâului Sărat" river. Circumstances of the discovery: research excavation made by D. Berciu in 1969. Context: settlement, level I, trench XIII/60, depth -2,60 m. Type: Demetz TKF II c-d. Technical data: bronze; lenght: $9,5 \mathrm{~cm}$. Fig. 2/3. Storage institution: Muzeul Județean Aurelain Sacerdoțeanu Vâlcea, Râmnicu Vâlcea, inv. No. Oc. 69402. Lit.: Berciu 1981, 30, 181, pl. 5/7, 12/3.

4. Poiana (Galați county). Site: "Cetățuia”. Circumstances of the discovery: research excavation made by R. Vulpe and E. Dunăreanu Vulpe in 1927. Context: settlement (?). Type: Demetz TKF I. Technical data: bronze; lenght: 4,9 cm. Fig. 2/4. Storage institution: Muzeul Teodor Cincu, Tecuci, inv. 7552 (personal remark, 2003). Lit.: Vulpe, Teodor 2003, 208, no. 33, 573, fig. 94/1.

5. Poiana (Galați county). Site: "Cetățuia”. Circumstances of the discovery: research excavation R. Vulpe şi A. Niţu in 1950. Context: settlement, area 
I-4 (data from the MNA file II 6126, written by A. D. Alexandrescu). Type: Demetz TKF I. Technical data: bronze; lenght: $5,15 \mathrm{~cm}$. Fig. $2 / 5$. Storage institution: Muzeul Naţional de Istorie a României, Bucharest, inv. 16355 (former inv. no. MNA II 6126). Lit.: inedit.

6. Poiana (Galați county). Site: "Cetățuia”. Circumstances of the discovery: the fibula was discovered by treasure hunters in the Z-R area of the prehistocic settlement and handed over to R. Vulpe on June 16, 1951 (data from the unpublished manuscript R. Vulpe, Poiana 1951 I, p. 62, MNA archive, Bucharest). Context: unknown. Type: Demetz TKF I. Technical data: bronze; lenght: $5 \mathrm{~cm}$. Fig. 2/6. Storage institution: Muzeul de Istorie Teodor Cincu, Tecuci, inv. 2405 (?). Lit.: Teodor, Țau 1997, 95, no. 34, fig. 4/2; Vulpe, Teodor 2003, 208, no. 34, fig. 94/2.

7. Poiana (Galați county). Site: "Cetățuia”. Circumstances of the discovery: research excavation S. Teodor ş.a., 1987, trench N. Context: settlement. Type: Demetz TKF I. Technical data: bronze; lenght: 4,8 cm. Fig. 2/7. Storage institution: Muzeul de Istorie Teodor Cincu, Tecuci, inv. 2408 (?). Lit.: Vulpe, Teodor 2003, 209, no. 39, 573, fig. 94/6.

8. Poiana (Galați county). Sit: "Cetățuia”. Circumstances of the discovery: research excavation R. Vulpe, 1950, trench $\mathrm{I}^{1}$, c. $4^{1}-11$. Context: settlement. Type: Demetz TKF I. Technical data: bronze; lenght: $2,7 \mathrm{~cm}$. Fig. $2 / 8$. Storage institution: Muzeul Național de Antichități, Bucharest. Lit.: Spânu 2019, 425, 427-429, 435, no. 8 , fig. $1 / 8$.

9. Poiana (Galați county). Site: "Cetățuia". Circumstances of the discovery: research excavation made by Silvia Teodor a.o. in 1990, trench P. Context: settlement. Type: Demetz TKF I (?). Technical data: bronze; lenght: $5,2 \mathrm{~cm}$; the foot and cathe-plate are missing. Fig. 2/9. Storage institution: Muzeul de Istorie Teodor Cincu, Tecuci, inv. 2407 (?). Lit.: Vulpe, Teodor 2003, 208, no. 37, 573, fig. 94/5.

10. Poiana (Galați county). Sit: "Cetățuia”. Circumstances of the discovery: săpături sistematice, R. Vulpe, 1950, secțiunea K. Context: aşezare (?). Fibulă cu şarnieră (?); decorul arcului ar putea corespunde variantei Demetz TKF I. Date tehnice: bronz; lenght: 4,7 cm. Fig. 2/10. Storage institution: Muzeul de Istorie Teodor Cincu, Tecuci, inv. 2473 (?). Lit.: Vulpe, Teodor 2003, 223, no. 248, 589, fig. 110/1.

11. Poiana (Galați county). Site: "Movila cu pietre”. Circumstances of the discovery: research excavation made by E. Dunăreanu Vulpe in 1928 (and not in 1927 as stated by Vulpe, Teodor 2003, 208). Context: tumulus; fibula provine în peretele camerei funerare (şi nu din "necropola monteoreană"). Type: Demetz TKF I. Date tehnice: bronz; lenght: 4,8 cm. Fig. 2/11. Storage institution: Muzeul de Istorie Teodor Cincu, Tecuci, inv. vechi 2406 (Vulpe, 
Teodor 2003, 208), inv. nou 16402 (informație Paul Ciubotaru, martie 2017). Lit.: Dunăreanu-Vulpe 1938, 164, fig. 15/3; Vulpe, Teodor 2003, 208, no. 35, 573, fig. 94/3; Spânu 2012b, 166-169, fig. 4; informații suplimentare din jurnalul manuscris al E. Dunăreanu Vulpe, Poiana 1928 (arhiva MNA, Bucureşti).

12. Poiana (Galați county). Site: "Movila Hârtop”. Circumstances of the discovery: research excavation made by R. Vulpe, 1931. Context: ustrinum under the tumulus (according to the unpublished manuscript R. Vulpe, Poiana 1931, MNA arhive, Bucharest). Type: Demetz TKF II a-b. Date tehnice: bronz; lenght: 4,2 cm. Fig. 2/12. Storage institution: Muzeul de Istorie Teodor Cincu, Tecuci. Lit.: Spânu 2009, 88-90, fig. 3, Spânu 2012a, 235, pl. 97/3; Spânu 2012b, 169-171, fig. 6/3.

13. Răcătău de Jos (Horgeşti commune, Bacău county). Site: "Cetățuia”. Circumstances of the discovery: research excavation made by V. Căpitanu, 1967-1988. Context: protohistoric settlement (?). Type: Demetz TKF I. Date tehnice: bronze; unspecified lenght. Fig. 2/13. Storage institution: Complexul Muzeal Iulian Antonescu, Bacău. Lit.: Căpitanu 1989, 120, fig. 10/4.

\section{Bibliography}

Babeş, Mircea. 2010. "Staţiunea geto-dacică de la Cârlomăneşti: dava sau centru religios?” Mousaios 15: 123-146.

Bemmann, Jan. 1999. "Norisch-pannonische Trachtbestandteile aus Mitteldeutschland. Zur Bedeutung fremd Sachguts am Beginn der älteren römischen Kaiserzeit in Mitteldeutschland." In Arbeits- und Forschungsberichte zur Sächsischen Bodendenkmalpflege 41, edited by Judith Oexle, 151-174. Stuttgart: Konrad Theiss

Berciu, Dumitru. 1981. Buridava dacică. Bucureşti: Editura Academiei Republicii Socialiste România.

Biaggio, Simona, 1991. I vetri romani provenienti dalle terre dell'attuale Cantone Ticino, vol. 1-2. Locarno: Armando Dado.

Blankenfeldt Ruth. 2015. "Fünfzig Jahre nach Joachim Werner: Überlegungen zur kaiserzeitleichen Kunst.” In Bilddenkmäler zur germanischen Götter- und Heldensage, edited by Wilhelm Heizmann and Sigmund Oehrl, 9-82. Göttingen: De Gruyter.

Bobi, Victor. 1987. "Două fibule dacice din colecțiile Muzeului Vrîncean, Vrancea.” Studii şi Comunicări (Focşani) 4: 507-509.

Böhme-Schönberger, Astrid. 1994. "Römische Kaiserzeit im Provinzialrömischen Gebiet und Beziehungen zur Germania magna” In Reallexikon der Germanischen Altertumskunde, Band 8 (Euhemerismus-Fichte, s. v. Fibeln und Fi- 
beltracht), edited by Johannes Hoops and Heinrich Beck, 511-523. Berlin-New York: de Gruyter.

Bossman, Arjen and Maarten de Weerd. 2004. "Velsen. The 1997 Excavation in the Early Roman Base and a Reappraisal of the Post-Kalkriese Velsen/ Vechten Dating Evidance." In: Archaeology in Confrontation: Aspects of Roman Military Presence in the Northwest. Studies in Honour of Hugo Thoen, edited by Frank Vermeulen, Kathy Sas and Wouter Dhaeze, 31-63. Ghent: Academia Press.

Căpitanu, Viorel. 1976. "Principalele rezultate ale săpăturilor arheologice în aşezarea geto-dacică de la Răcătău (jud. Bacău).” Carpica 8: 49-120.

Căpitanu, Viorel. 1989. "Obiecte de podoabă şi piese vestimentare descoperite în dava de la Răcătău, județul Bacău.” Carpica 20: 97-124.

Dana, Dan. 2000. "Dacii şi lupii. Pe marginea teoriei lui Mircea Eliade." Studii şi Cercetări de Istorie Veche şi Arheologie 51, 3-4: 153-174.

Demetz, Stefan. 1993. "Fibule a testa di animale dal Trentino. Considerazioni sulla possibilità di ricerche tipologiche su fibule della prima età imperial." Archeologia delle Alpi 2: 59-71.

Demetz, Stefan. 1999. Fibeln der Spätlatène- und Frühen Kaiserzeit in den Alpenländern. Frühgeschichtliche und provinzialrömische Archäologie. Materialien und Forschungen, Band 4. Leidorf: Rahden/Westf.

Demetz, Stefan. 2000. "Fibeln mit beissendem Tierkopf (TKF - Tierkopffibeln).” Sborník Národního Muzea v Praze/Acta Musei Nationalis Pragae 54: 15-36.

Dunăreanu-Vulpe, Ecaterina. 1938. "La nécropole de l'âge du bronze de Poiana." Dacia 5-6, 1935-1936: 151-167.

Eggers, Hans Jürgen. 1953. "Lübsow, ein germanischer Fürstensitz der älteren Kaiserzeit.” Prähistorische Zeitschrift 34-35, 2, 1949-1950: 58-111.

Eschbaumer, Pia. 2011. "Frühe Italische Sigillata (Arretina) in Asciburgium." In Terra Sigillata in den germanischen Provinzen: Kolloquium Xanten, 13.14. November 2008. Xantener Berichte 20, edited by Bernd Liesen, 21-32. Mainz am Rhein: Philipp von Zabern.

Fink, Robert Orwill. 1958. "Hunt's Pridianum, British Museum Papyrus 2851." The Journal of Roman Studies 48: 102-116.

Florea, Gelu. 2011. Dava et Oppidum. Débuts de la genèse urbaine en Europe au deuxième âge du Fer. Cluj-Napoca: Académie Roumaine. Centre d'études Transylvaines.

Garbsch, Jochen. 1965. Die Norisch-pannonische Frauentracht im 1. und 2. Jahrhundert. München: Beck'sche.

Gebühr, Michael. 1974. "Zur Definition älterkaiserzeitlicher Fürstengräber vom Lübsow-Typ.” Prähistorische Zeitschrift 49: 82-128. 
Gillam, James Frank. 1962. “The Moesian Pridianum.” In Hommages à Albert Grenier, edited by Marcel Renard, Collection Latomus 58, 747-757. Bruxelles: Latomus.

Glodariu, Ioan. 1974. Relațiile comerciale ale Daciei cu lumea elenistica şi romană. Cluj-Napoca: Dacia.

Glodariu, Ioan. 1976. Dacian Trade with the Hellenistic and Roman World. Oxford: British Archaeological Reports, Suppl. Ser. 8.

Grabherr, Gerald. 2015. "Zur römischen Frühzeit im Südlichen Alpinen Teil Raetiens:" In Der obere Donauraum 50 v. bis 50 n. Chr., edited by Ute Lohner-Urban and Peter Scherrer, 153-169. Berlin: Frank\&Timme.

Gugl, Christian. 2001. "Das Umland Teurnias vom 2. Jahrhundert v. Chr. bis ins 1. Jahrhundert n. Chr. Eine Studie zur Siedlungskontinuität von der Latène- und Römerzeit im oberen Drautal.” Arheološki vestnik 52: 303-349.

Hayes John W. 1973. "Roman Pottery from the South Stoa at Corinth." Hesperia 42: 416-470.

Hayes, J. W. 2008. "Roman Pottery. Fine-Ware Imports.” In The Athenian Agora. Results of Excavation conducted by the American School of Classical Studies at Athens, Volume 32. Princeton, New Jersey: The American School of Classical Studies at Athens.

Hedeager, Lotte and Kristian Kristiansen. 1981. "Bendstrup - en fyrstegrav fra den romerske jernadel, dens sociale historiske miljø / Bendstrup - a Princely Grave from the Early Roman Iron Age: Its Social and Historical Context." Kuml: Arbog og Jysk Arkaologisk Selskab: 81-165.

Hellström, Kirsten. 2018. Fibeln und Fibeltracht der Sarmatischen Zeit im Nordschwarzmeergebiet (2. Jh. v. Chr. - 3. Jh. n. Chr.), In Archäologie in Eurasien, edited by Sven Hansen, Band 39, Bonn: Habelt.

Horedt, Kurt.1973. “Die dakische Silberfunde.” Dacia 17: 122-165.

Isings, Clasina. 1957. Roman Glass from Dated Finds, Groeningen, Djakarta: J.B. Wolters.

Isings, Clasina, Sophia M. E. van Lith. 1992. Romeins glas. Nijmegen: Vereniging van Vrienden van het Museum Kam.

Jahn, Martin, 1952. "Fernhandel zwischen Ostalpen und Skandinavien in der frühen Kaiserzeit." Jahresschrift für Mitteldeutsche Vorgeschichte 36:93-101.

Kropotov, Viktor V. 2010. Fibuly sarmatskoj jepohi, Kiev: ADEF-Ukraina.

Matei-Popescu, Florian. 2018. "The Thracian strategiae in Scythia Minor." In Society, Kings, Gods. In memoriam professoris Margaritae Tacheva, edited by Dilyana Boteva-Boyanova, Peter Delev and Julia Tzevetkova, Jublaeus VII, 107118. Sofia: University St. Kliment Ohridski. 
Menke, Manfred. 1974. “"Rätische” Siedlungen und Bestattungsplätze der frührömischen Kaiserzeit im Voralpenland.” In Studien zur vor- und frühgeschichtlichen Archäologie. Festschrift für Joachim Werner zum 65. Geburtstg, edited by Georg Kossack and Günter Ulbert, 141-159. München: Beck.

Menke, Manfred. 1977. "Zur Struktur und Chronologie der spätkeltischen und frührömischen Siedlungen im Reichenhaller Becken.” In Ausklang der Latène-Zivilisation und Anfänge der germanischen Besiedlung im mittleren Donaugebiet, edited by B. Chropovský, 223-238. Bratislava: Veda.

Michalska, Danuta, Magdalena Benysek and Jacek Andrzejowski. 2015. "IV.7. Czarnówko, Fpl. 5 - die ${ }^{14}$ C-Datierung." In Czarnówko, Fpl. 5. Vor- und frühgeschichtliche Gräberfelder in Pommern, edited by Jacek Andrzejowski, 253256, Teil 1. Lębork, Warszawa: Muzeum.

Mocanu, Marian. 2016. "Importuri de terra sigillata în spațiul vest-pontic." Peuce 14: 119-128.

Müller, Rosemarie. 1985. Die Grabfunde der Jastorf- und Latènezeit an unterer Saale und Mittelelbe. Veröffentlichungen des Landesmusuem für Vorgeschichte in Halle 38. Berlin: Deutscher Verlag der Wissenschaften.

Quast, Dieter. 2009. “Frühgeschichtliche Prunkrgäberhorizonte.” In Aufstieg und Untergang. Zwischenbilanz des Forschungsscherpunktes «Studien zu Genese und Struktur von Eliten in Vor- und Frühgeschichtlichen Gesellschaften», edited by Markus Egg and Dieter Quast, 107-142. Monographien des Römisch-Germanischen Zentralmuseums 82, Mainz: Romisch-Germanisches Zentralmuseum.

Rustoiu, Aurel. 1989. "Fibule dacice cu ornamente zoomorfe." Apulum 26: 135-145.

Rustoiu, Aurel. 1997. Fibulele din Dacia Preromană, Bibliotheca Thracologica 22. Bucureşti: Institutul român de tracologie.

Rustoiu, Aurel. 2000: "Grupa răsăriteanã a podoabelor dacice (un studiu privind relapiile inter-regionale în Dacia preromanã în sec. I î.e.n. - I e.n.).” Analele Banatului 1999-2000, 7-8: 325-365.

Rustoiu, Aurel. 2002: "Die östliche Gruppe des dakischen Schmuckes. Eine Untersuchung bezüglich der interregionalen Beziehungen im vorrömischen Dakien im 1. Jh. v. Chr. - 1 Jh. n. Chr." In Interregionale und Kulturelle Beziehungen im Karpatenraum (2. Jahrtausend v. Chr. - 2 Jahrtausend n. Chr.), edited by Aurel Rustoiu and Adrian Ursuțiu, 191-226. Cluj-Napoca: Nereamia Napocae.

Schuster, Jan. 2010. Lübsow: älterkaiserzeitliche Fürstengräber im nördlichen Mitteleuropa. Bonner Beiträge zur vor- und frühgeschichtlichen Archäologie, 12. Bonn: Rheinische Friedrich-Wilhelms-Universität.

Sedlmayer, Helga. 2009. Die Fibeln von Magdalensberg. Funde der Grabungsjahre 1948-2002 und Altfunde des 19. Jahrhundert, In Archäologische Forschun- 
gen zu den Grabungen auf dem Magdalensberg, edited by G. Piccottini, 16. Klagenfurt am Wörthersee: Verlag des Landesmuseums Kärnten.

Spânu, Daniel. 2009. “The Spoon-Bow Fibula Retrieved from the Giurgiu Customs. Observations on the Spoon-Bow Fibulae from the Lower Danube Area." In Treasure Lost, Treasure Regained, edited by Cristina Alexandrescu, Adrian Ioniţă; Andrei Măgureanu and Bogdan Florin Tănăsescu, 85-94. The Heritage Series No. 1. Giurgiu: Pelican.

Spânu, Daniel. 2012a. Tezaurele dacice. Creația în metale prețioase din Dacia preromană. Bucureşti: Simetria.

Spânu, Daniel. 2012b. "Zur Transformation der Bestattungssitten östlich der Karpaten im Kontext der römischen Eroberung Dakiens.” Prähistorische Zeitschrift 87, 1: 161-188.

Spânu, Daniel. 2019. "Un mic lot de fibule inedite de la Poiana în colecțiile Muzeului Național de Antichități din București." In Contribuţii la preistoria şi istoria antică a spațiului carpato-danubiano-pontic. In honorem professoris Ion Niculiță natalia sua octogesima celebrantis, edited by Aurel Zanoci and Mihail Băț, 421-438. Chişinău: Cartdidact.

Šribar, Vinko. 1968. “K absolutni kronologiji najdb iz zgodnje Emone.” Arheološki Vestnik 19: 445-453.

Syme, Roland. 1959. “The Lower Danube under Trajan.” The Journal of Roman Studies 49: 26-33.

Tejral, Jaroslav. 1998. "Die Grundprobleme der kaiserzeitlichen Fibelforschung im norddanubischen Raum.” Forschungen zur Archäologie im Land Brandenburg 5: 387-398.

Ulbert, Günter. 1960. "Alpenländische Fibeln aus dem frührömischen Kastell Rheingönheim.” Mitteilungen des Historischen Vereins der Pfalz 58: 49-55.

Ursachi, Vasile. 1987. "Cetatea dacică de la Brad." Thraco-Dacica 8, 1-2: 100-126.

Ursachi, Vasile. 1995. Zargidava. Cetatea dacică de la Brad, Bibliotheca thracologica 10. Bucureşti: Institutul Român de Tracologie.

Völling, Thomas. 2005. Germanien an der Zeitenwende. Studien zum Kulturwandeln beim Übergang vorrömischen Eisenzeit zur älteren römischen Kaiserzeit in der Germania Magna. In British Archaeologial Reports, edited by Holger Baitinger, Alexandru Popa and Gabriele Rasbach, International Series 1360. Oxford: Archaeopress.

Vulpe, Radu. 1957. "La civilisation dace et ses problèmes à la lumière des dernières foilles de Poiana en basse Moldavie." Dacia 1: 143-164.

Vulpe, Radu. 1960. "Muntenia şi Moldova de Jos în timpul lui Traian în lumina unei noi lecturi a papirusului Hunt.” Studii Clasice 2: 337-359. 
Vulpe, Radu. 1964. "Ptolemy and the ancient geography of Moldavia." Studii Clasice 6: 233-246.

Vulpe, Alexandru 1976. "La nécrople tumulaire gète de Popeşti." Thraco-Dacica 1: 193-215.

Vulpe, Radu, Ecaterina Vulpe, A. Nițu, Nicolae Gostar and Eugen Chirilă. 1952. "Şantierul Poiana." Studii şi Cercetări de Istorie Veche 3: 191-230

Vulpe, Radu and Silvia Teodor. 2003. Piroboridava. Așezarea geto-dacică de la Poiana, Bibliotheca Thracologica 39. București: Institutul Român de Tracologie.

Werner, Joachim. 1954. "Fibeln aus Aquileia." In Origines. Raccolta di scritti in onore di Mons. Giovanni Baserga, 151-159. Società Archeologica Comense, Como: Antonio Noseda.

\title{
Fibule cu protome canide (Tierkopffibeln) din România
}

\section{Rezumat}

În stadiul actual al cercetării, pe teritoriul României au fost descoperite 12 fibule cu protomă canidă pe arc (germ. Tierkopffibeln). Cu excepția unui exemplar de la Ocnița (Valahia), toate celelalte provin din spațiul est-carpatic (Moldova). Aceste fibule oferă unele indicii prețioase pentru cronologia locală a epocii imperiale timpurii și permit unele deslușiri in privința fenomenelor de circulație a importurilor romane și de aculturație în Dacia preromană.

Cuvinte cheie: fibule cu protomă canidă; epocă imperială timpurie, Dacia pre-romană, importuri, aculturație

\author{
Daniel Spânu, \\ Institute of Archaeology, Bucharest, Romania. \\ E-mail: hazdrik@yahoo.com
}

